\title{
Pengaruh Pemberian LKS Latihan Soal Terstruktur Terhadap Pemahaman Konsep Isomer Senyawa Hidrokarbon Pada Siswa Kelas XI IPA SMA Negeri 4 Palangka Raya Tahun Ajaran 2018/2019
}

\author{
Corry Anggraini*, Abudarin, Nopriawan Berkat Asi \\ Program Studi Pendidikan Kimia, Jurusan Pendidikan MIPA, FKIP, Universitas \\ Palangka Raya, Indonesia \\ E-mail: nopriawanb@gmail.com
}

Diterima: 02 Maret 2020; Disetujui: 16 Maret 2020; Diterbitkan: 22 Maret 2020

\begin{abstract}
ABSTRAK
Tujuan penelitian ini adalah untuk mendeskripsikan pengaruh pemberian LKS latihan soal terstruktur terhadap pemahaman konsep isomer senyawa hidrokarbon pada siswa kelas XI-IPA SMA Negeri 4 Palangka Raya tahun ajaran 2018/2019. Penelitian ini merupakan penelitian eksperimen dengan desain penelitian Pretest Posttest Control Group Design dan melibatkan sebanyak 56 siswa dari dua kelas XI IPA SMA Negeri 4 Palangka Raya sebagai sampel yang ditentukan dengan teknik Cluster random sampling, yaitu siswa kelas XI IPA-1 (kelas eksperimen) sebanyak 29 orang siswa dan siswa kelas XI IPA-2 (kelas kontrol) sebanyak 27 orang siswa. Instrumen yang digunakan berupa soal tes pemahaman konsep C-1 yang dimuat dalam tes I, tes II, LKS latihan soal terstruktur dan LKS latihan soal. Data tes I diperoleh setelah pembelajaran langsung dan data tes II diperoleh setelah pembelajaran menggunakan LKS latihan soal terstruktur dan LKS latihan soal. Hasil penelitian menunjukkan bahwa pemberian LKS latihan soal terstruktur berpengaruh terhadap pemahaman konsep isomer senyawa hidrokarbon pada siswa kelompok bawah kelas XI IPA SMA Negeri 4 Palangka Raya tahun ajaran 2018/2019. Rata-rata pemahaman konsep siswa kelas eksperimen $(85,60)$ lebih tinggi dari kelas kontrol $(59,25)$. LKS latihan soal terstruktur memberikan pengaruh terhadap siswa kelompok bawah dan siswa kelompok atas.
\end{abstract}

Kata kunci: Isomer Senyawa Hidrokarbon, LKS Latihan Soal Terstruktur

\section{PENDAHULUAN}

Belajar pada hakekatnya adalah "perubahan" yang terjadi didalam diri seseorang setelah melakukan aktifitas belajar (Djamariah, 2006). Berhasil tidaknya suatu proses pembelajaran tidak terlepas dari peran guru didalamnya. Hamalik (2007) menyatakan "Guru berkewajiban menyediakan lingkungan yang serasi agar aktivitas belajar menuju kearah sasaran yang diinginkan". Penggunaan media yang cocok, bahan ajar yang sesuai, metode yang tepat, dan pendekatan yang benar merupakan salah satu faktor penting yang harus dilakukan oleh seorang guru. Oleh karena itu, guru sebagai pengelola pengajaran dituntut mampu 
mencari usaha yang dapat membangkitkan minat dan semangat belajar siswa. Pembelajaran kimia disekolah diajarkan secara berkesinambungan artinya dalam mengajarkan suatu materi tidak diberikan secara sekaligus, tetapi diberikan secara bertahap dan berkaitan antara satu tahap dengan tahap berikutnya. Sehingga penguasaan konsep ditingkat dasar harus dikuasai jika tidak maka siswa akan mengalami kesulitan dalam menguasai materi berikutnya yang berkaitan dengan konsep tersebut.

Mata pelajaran kimia sarat dengan konsep, sehingga diperlukan pemahaman yang mendalam terhadap konsep dasar kimia. Banyaknya konsep kimia yang bersifat abstrak yang harus dipelajari siswa dalam waktu cukup singkat menjadikan pelajaran kimia merupakan salah satu mata pelajaran yang dianggap sulit bagi siswa. Kebanyakan siswa cenderung pasif dalam mengikuti pembelajaran, karena kurang bervariasinya model serta media pembelajaran yang digunakan guru dalam proses pembelajaran. Pemahaman konsep kimia siswa menjadi kunci penting dalam kesuksesan pembelajaran kimia. Kesalahan konsep kimia berimbas pada ketidak pahaman siswa siswa terhadap materi kimia. Pemahaman konsep yang baik berimbas positif pada hasil belajar siswa.

Salah satu Sub pokok bahasan yang dipelajari siswa kelas XI SMA adalah isomer senyawa hidrokarbon, berdasarkan penelitian yang dilakukan oleh Desi (2015) tentang "Kesulitan Memahami Konsep Isomer Senyawa Hidrokarbon Pada Siswa Kelas XI MIA SMA Negeri di Kota Muara Teweh Semester Genap Tahun Ajaran 2014/2015" menunjukkan sebagian besar siswa-siswi mengalami kesulitan dalam memahami konsep Isomer Senyawa Hidrokarbon. Persentase rata-rata siswa yang tidak memahami konsep adalah 64,1\%. Mencakup konsep menerapkan kekhasan atom karbon, menentukan jumlah ikatan karbon untuk (alkana, alkena, dan alkuna), penulisan struktur senyawa serta definisi dari isomer rangka, isomer posisi, dan isomer geometri dan terlebih lagi belum adanya upaya dan fasilitas sebagai media bahan ajar yang didesain dalam pembelajaran. Guru memiliki tugas untuk menyediakan bahan ajar yang dapat memotivasi siswa untuk belajar mandiri dalam menemukan suatu konsep dan aplikasinya. Salah satu bahan ajar yang dapat digunakan yaitu LKS (Lembar Kerja Siswa).

Berdasarkan permasalahan tersebut, diharapkan dengan membuat media bahan ajar berupa LKS yang dirancang sedemikian rupa dapat membantu siswa dan membimbing siswa dalam proses pembelajarannya, salah satu jenis LKS yang dapat digunakan sebagai alat bantu pembelajaran adalah LKS latihan soal terstruktur. LKS latihan soal terstruktur adalah latihan soal yang didalamnya memuat soal beserta langkah-langkah penyelesaiannya yang disajikan secara terstruktur. Mengingat materi Isomer Senyawa Karbon sangat erat kaitannya dengan konsep-konsep yang diterapkan dalam pernulisan struktur senyawa hidrokarbon. Maka dengan LKS latihan soal terstruktur ini dapat mempermudah siswa menyelesaikan soal tentang Isomer Senyawa Karbon. Penelitian tentang pengaruh LKS latihan soal terstruktur juga telah dilakukan oleh Otania (2019) dan Asi (2019).

Penelitian yang dilakukan oleh Mutmainah (2013) tentang "Pengaruh Pemberian LKS-Penyelesaian Soal Terstruktur terhadap Pemahaman Konsep pH Larutan Asam Pada Siswa Kelas XI IPA SMAN-1 Menthobi Raya Tahun Ajaran 2012/2013". Kemampuan siswa memahami konsep pH Larutan Asam setelah pembelajaran menggunakan LKS-latihan soal terstruktur meningkat dari $0 \%$ 
menjadi 76\%. LKS latihan soal terstruktur dapat berpengaruh positif pada hasil belajar siswa dan mempermudah siswa dalam memahami konsep kimia. Berdasarkan penelitian tersebut, peneliti ingin mengetahui bagaimana pengaruh pemberian LKS latihan soal terstruktur terhadap pemahaman konsep Isomer Senyawa Hidrokarbon. Dimana pada penelitian ini media pembelajaran yang ingin digunakan adalah LKS latihan soal terstruktur.

Materi kimia yang dibahas pada penelitian ini hanya pada subpokok bahasan isomer senyawa hidrokarbon yang dipelajari pada kelas XI yang mencakup materi keisomeran rangka, keisomeran posisi, keisomeran geometri (cis-trans), keisomeran pada alkana, keisomeran pada alkena dan keisomeran pada alkuna. Rumusan masalah dalam penelitian ini adalah pemberian latihan soal terstruktur berpengaruh terhadap pemahaman konsep isomer senyawa hidrokarbon pada siswa kelas XI SMAN 4 Palangka Raya Tahun Ajaran 2018/2019? Berdasarkan masalah yang telah dikemukakan, maka tujuan dalam penelitian ini adalah mendeskripsikan pengaruh pemberian latihan soal terstruktur terhadap pemahaman konsep isomer senyawa hidrokarbon pada siswa kelas XI IPA SMAN 4 Kota Palangka Raya tahun ajaran 2018/2019.

\section{METODOLOGI PENELITIAN}

Metode penelitian yang digunakan dalam penelitian ini adalah metode eksperimen. Adapun desain eksperimen penelitian ini adalah Pretest-Posttest Control Group Design yang digambarkan pada tabel berikut:

Tabel 1. Tabel Desain Penelitian

\begin{tabular}{lcccc}
\hline \multicolumn{1}{c}{ Kelompok } & Pembelajaran & Tes I & Perlakuan & Tes II \\
\hline Eksperimen (E) & $\mathbf{P}_{1}$ & $\mathbf{Y}_{1 \mathrm{e}}$ & $\mathbf{X}$ & $\mathbf{Y}_{2 \mathrm{e}}$ \\
\hline Kontrol (K) & $\mathbf{P}_{1}$ & $\mathbf{Y}_{1 \mathrm{k}}$ & - & $\mathbf{Y}_{2 \mathrm{k}}$ \\
\hline
\end{tabular}

Penelitian ini dilakukan di SMA Negeri 4 Palangka Raya pada siswa kelas XI jurusan IPA tahun ajaran 2018/2019. Populasi dalam penelitian ini berjumlah 210 siswa yang tersebar dalam 6 kelas. Teknik pengambilan sampel menggunakan cluster ramdom sampling dengan cara undian, Setelah dilakukan pengundian terpilih dua kelas yaitu kelas XI IPA 1 sebagai kelas eksperimen (29 siswa) dan kelas XI IPA 2 sebagai kelas control (27 siswa). Soal tes pemahaman konsep tes I dan Tes II dibuat dalam bentuk soal essay tertulis yang berjumlah 3 butir soal. Instrumen penelitian ini dibuat berdasarkan pembelajaran yang ingin dicapai. Instrumen dikembangkan dengan kisi-kisi berdasarkan indikator yang mengacu pada kurikulum 2013 revisi. Soal tes I dan tes II memiliki soal yang berbeda berbeda serta mempunyai bobot yang berbeda. Pada latihan soal terstruktur disusun dengan memberikan langkah-langkah penyelesaian, sedangkan pada latihan soal dirancang tanpa disertai langkah-langkah penyelesaian. Teknik pengumpulan data menggunakan metode dokumentasi dan metode eksperimen.

Ada 4 tahap yang digunakan dalam pengumpulan dan pengolahan data. Tahap 1, semua kelas sampel diberikan penbelajaran langsung tentang konsep isomer senyawa hidrokarbon dengan materi ajar dan jumlah jam belajar yang sama. Tahap 2, semua kelas sampel diberikan tes I untuk mengetahui (mengukur) kemampuan awal seluruh kelas sampel setelah dilakukan pembelajaran langsung pada materi isomer senyawa hidrokarbon. Tahap 3, kelas yang berperan sebagai kelas eksperimen dilakukan pembelajaran langsung dengan pemberian Latihan 
Soal Terstruktur, sedangkan kelas kontrol dilakukan pembelajaran langsung dengan pemberian Latihan Soal. Tahap 4 yaitu tahap pengukuran penguasaan konsep oleh siswa dengan memberikan tes II pada kedua kelas yakni kelas eksperimen dan kelas kontrol. Data yang diperoleh kemudian dianalisis dengan teknis analisis data penelitian ini. Hasil tes setiap siswa diolah dengan memberi skor pada lembar jawaban dan menjumlahkan skor yang diperoleh oleh masingmasing siswa dan di konversi dalam bentuk persentase nilai (\%).

Variabel yang digunakan dalam penelitian ini terdiri dari 2 variabel, yaitu variabel terikat yaitu pemahaman konsep isomer senyawa hidrokarbon yang diukur menggunakan tes pemahaman konsep dan variabel bebas jenis latihan soal yang diberikan setelah pembelajaran langsung yaitu latihan soal yang dilengkapi dengan langkah-langkah penyelesaian soal yang disebut latihan soal terstruktur. Instrument penelitian yang berupa butir-butir soal essay yang berjumlah 3 butir, sebelum digunakan terlebih dahulu di uji cobakan kepada anggota populasi yang tidak menjadi sampel yaitu siswa kelas XII IPA 1 sebanyak 34 orang siswa. Uji coba dilakukan untuk mengetahui validitas butir soal, reliabilitas instrumen, indeks kesukaran dan daya beda. Hasil uji coba instrument kemudian dianalisis dengan menggunakan uji yang telah dikemukaan sebelumnya dalam penelitian ini untuk mengetahui kevalidan dan keandalan (reliabel) suatu soal. Setelah instrument dianggap valid dan reliabel, kemudian instrument disebarkan kembali kepada sampel penelitian untuk memperoleh data. Setelah data terkumpul kemudian dilakukan uji prasyarat analisis yaitu dengan uji normalitas dan uji keseimbangan untuk mengetahui normal tidaknya distribusi data pada sampel dan mengetahui apakah data kemampuan awal kedua kelas seimbang. Setelah kriteria pada uji prasyarat analisis terpenuhi, kemudian dilakukan analisis uji t (uji hipotesis) untuk mengetahui pengaruh variabel bebas (jenis latihan yaitu LKS latihan soal terstruktur) terhadap variabel terikat (pemahaman konsep isomer senyawa hidrokarbon yang diukur menggunakan tes pemahaman konsep). Pengujian hipotesis dalam penelitian ini menggunakan rumus uji-t .

$$
\mathrm{t}=\frac{\bar{x}_{1}-\bar{x}_{2}}{\sqrt{\frac{\left(n_{1}-1\right) S_{1}^{2}+\left(n_{2}-1\right) S_{2}^{2}}{n_{1}+n_{2}-2}\left(\frac{1}{n_{1}}+\frac{1}{n_{2}}\right)}}
$$

Jika $t_{\text {hitung }}>t_{\text {tabel }}$ pada $\mathrm{db}=\left(\mathrm{n}_{1}+\mathrm{n}_{2}-2\right)$ dan taraf signifikan $5 \%$ maka $\mathrm{H}_{\mathrm{o}}$ ditolak dan $\mathrm{H}_{\mathrm{a}}$ diterima. Jika sebaliknya yakni $\mathrm{t}_{\text {hitung }} \leq \mathrm{t}_{\text {tabel }}$ maka $\mathrm{H}_{\mathrm{o}}$ diterima dan $\mathrm{H}_{\mathrm{a}}$ ditolak.

Dalam penelitian ini penguji hipotesis menggunakan uji $\mathrm{t}$ (dua pihak) dengan taraf signifikan $5 \%$ sebagai berikut.

$\mathrm{H}_{\mathrm{o}}\left(\mu_{1}=\mu_{2}\right) \quad$ : Pemberian latihan soal terstruktur setelah pembelajaran langsung tidak berpengaruh terhadap pemahaman konsep isomer senyawa hidrokarbon pada siswa kelas XI IPA SMA Negeri 4 Palangka Raya tahun ajaran 2018/2019.

$\mathrm{H}_{\mathrm{a}}\left(\mu_{1} \neq \mu_{2}\right) \quad$ : Pemberian latihan soal terstruktur setelah pembelajaran langsung berpengaruh terhadap pemahaman konsep isomer senyawa hidrokarbon pada siswa kelas XI IPA SMA Negeri 4 Palangka Raya tahun ajaran 2018/2019. 
Pengujian hipotesis penelitian menggunakan tes akhir (tes II) dari kelas eksperimen dan kelas kontrol. $\mu_{1}$ yaitu pemahaman konsep isomer senyawa hidrokarbon hasil pembelajaran langsung menggunakan latihan soal terstruktur dan $\mu_{2}$ yaitu pemahaman konsep isomer senyawa hidrokarbon hasil pembelajaran langsung menggunakan latihan soal.

\section{HASIL PENELITIAN DAN PEMBAHASAN}

Sebelum dilakukan pengambilan data, terlebih dahulu dilakukan simulasi pembelajaran bertujuan untuk melihat kesesuaian butir soal dengan indikator serta kesediaan alokasi waktu. Pelaksanaan simulasi pembelajaran dilakukan di SMA Negeri 4 Palangka Raya pada hari Rabu, 19 September 2018 di kelas XII-IPA 1 berjumlah 34 siswa. Penelitian ini dilakukan terhadap siswa kelas XI-IPA SMA Negeri 4 Palangka Raya semester ganjil tahun ajaran 2018/2019. Sampel penelitian sebanyak 56 siswa yang terdiri dari dua kelas yaitu kelas eksperimen dan kelas kontrol. Pada kelas XI-IPA 1 sebagai kelas eksperimen jumlah siswa yang mengikuti pembelajaran sebanyak 29 siswa dan kelas X-IPA 2 sebagai kelas kontrol jumlah siswa yang mengikuti pembelajaran sebanyak 27 siswa. Pada kelas eksperimen diberi perlakuan yakni diberikan latihan soal yang disertai langkahlangkah penyelesaian soal yang dibuat dalam bentuk latihan soal terstruktur setelah pembelajaran langsung dan kelas kontrol diberikan latihan soal tak terstruktur, tetapi tidak diberikan langkah-langkah penyelesaian soal.

Pembelajaran dilakukan pada kelas XI-IPA 1 sebagai kelas eksperimen yang diberikan latihan soal terstruktur. Proses pengambilan data penelitian dilaksanakan dengan 1 kali pertemuan dengan alokasi waktu 4 x 45 menit pada hari Selasa, 25 September 2018 yang diikuti oleh 29 orang siswa. Pembelajaran dilakukan pada kelas XI-IPA 2 sebagai kelas kontrol yang diberikan latihan soal tak terstruktur. Proses pengambilan data penelitian dilaksanakan dengan 1 kali pertemuan dengan alokasi waktu 4 x 45 menit pada hari Rabu, 26 September 2018 yang diikuti oleh 27 orang siswa.

Dalam penelitian ini 4 tahapan dalam pelaksanaan pengambilan data yaitu tahap 1, semua kelas sampel diberikan penbelajaran langsung tentang konsep isomer senyawa hidrokarbon dengan materi ajar dan jumlah jam belajar yang sama selama 30 menit. Tahap 2, semua kelas sampel diberikan tes I selama 45 menit untuk mengetahui (mengukur) kemampuan awal seluruh kelas sampel setelah dilakukan pembelajaran langsung pada materi isomer senyawa hidrokarbon. Tahap 3, kelas yang berperan sebagai kelas eksperimen dilakukan pembelajaran langsung dengan pemberian Latihan Soal Terstruktur, sedangkan kelas kontrol dilakukan pembelajaran langsung dengan pemberian Latihan Soal selama 35 menit. Tahap 4 yaitu tahap pengukuran penguasaan konsep oleh siswa dengan memberikan tes II pada kedua kelas yakni kelas eksperimen dan kelas control selama 55 menit.

Nilai tes I pada kelas eksperimen memiliki nilai terendah 6,25 dan nilai tertinggi 81,25. Mean nilai tes I pada kelas eksperimen adalah 28,02 dan standar deviasi 17,53. Distribusi frekuensi nilai tes I kelas eksperimen bahwa nilai ratarata siswa kelas eksperimen terletak pada interval 19-31 sehingga, 7 orang atau sekitar 24,14\% pada kelas eksperimen mendapat nilai dibawah rata-rata dan 22 orang atau sekitar $75,86 \%$ mendapat nilai diatas rata-rata. Nilai tes II pada kelas eksperimen memiliki nilai terendah 46,56 dan nilai tertinggi 100. Mean nilai tes II 
pada kelas eksperimen adalah 85,60 dan standar deviasi 12,40. Distribusi frekuensi nilai tes II kelas eksperimen bahwa nilai rata-rata siswa kelas eksperimen terletak pada interval 86-95 sehingga, 10 orang atau sekitar 34,48\% pada kelas eksperimen mendapat nilai dibawah rata-rata dan 19 orang atau sekitar $65,52 \%$ mendapat nilai diatas rata-rata. Nilai tes I pada kelas kontrol memiliki nilai terendah 6,25 dan nilai tertinggi 81,25. Mean nilai tes I pada kelas kontrol adalah 23,15 dan standar deviasi 20,72. Distribusi frekuensi nilai tes I kelas kontrol bahwa nilai rata-rata siswa kelas kontrol terletak pada interval 19-31 sehingga, 13 orang atau sekitar $48,15 \%$ pada kelas kontrol mendapat nilai dibawah rata-rata dan 14 orang atau sekitar 51,85\% mendapat nilai diatas ratarata. Nilai tes II pada kelas kontrol memiliki nilai terendah 16,88 dan nilai tertinggi 100. Mean nilai tes II pada kelas kontrol adalah 59,25 dan standar deviasi 23,30. Distribusi frekuensi nilai tes II kelas kontrol bahwa nilai rata-rata siswa kelas kontrol terletak pada interval 46-60 sehingga, 6 orang atau sekitar 22,22\% pada kelas kontrol mendapat nilai dibawah rata-rata dan 21 orang atau sekitar $77,78 \%$ mendapat nilai diatas rata-rata.

Berdasarkan hasil uji prasyarat analisis pertama yaitu uji normalitas yang berguna untuk mengetahui data dari sampel penelitian berasal dari populasi yang berdistribusi normal atau tidak. Uji normalitas dilakukan menggunakan bantuan microsoft excel, untuk menerima atau menolak asumsi normalitas adalah dengan cara membandingkan nilai sig (positif) dengan nilai probabilitas 0,05 , maka data berdistribusi normal. Dari hasil uji normalitas diperoleh hasil untuk tes I dan tes II pada kelas eksperimen dan kelas control dapat dilihat pada tabel 2 dengan nilai probabilitas diatas 0,05 dinyatakan berdistribusi normal pada tingkat kepercayaan $95 \%$.

Tabel 2. Rangkuman Uji Normalitas Data Nilai Tes I dan Tes II Kelas Eksperimen dan Kelas Kontrol

\begin{tabular}{llllll}
\hline Data tes I & $\mathbf{N}$ & $\mathbf{A}$ & $\chi^{2}$ hitung & $\chi^{2}$ tabel & Kesimpulan \\
\hline Eksperimen & 29 & 0,05 & 12,14 & 12,59 & Normal \\
Kontrol & 27 & 0,05 & 8,28 & 12,59 & Normal \\
Data tes II & $\mathbf{N}$ & $\mathbf{A}$ & $\chi^{2}$ hitung & $\chi^{2}$ tabel & Kesimpulan \\
Eksperimen & 29 & 0,05 & 10,75 & 12,59 & Normal \\
Kontrol & 27 & 0,05 & 4,01 & 12,59 & Normal \\
\hline
\end{tabular}

Hasil uji prasyarat analisis kedua yaitu uji keseimbangan. Tujuan uji keseimbangan adalah untuk mengetahui apakah data kemampuan awal kedua kelas seimbang. Adapun ringkasan hasil uji keseimbangan yang dilakukan menggunakan bantuan Microsoft Excel. Dari hasil uji keseimbangan rata-rata pemahaman awal siswa pada kelas control dan kelas eksperimen terhadap pemahaman konsep isomer senyawa hidrokarbon menunjukkan data nilai tes I kedua kelas sampel diperoleh $\mathrm{t}_{\text {hitung }}=0,95$ sedangkan $\mathrm{t}_{\text {tabel }}=1,67$ pada taraf signifikansi $5 \%$ dan $\mathrm{dk}=n_{1}+n_{2}-2=29+27-2=54$. Karena $\mathrm{t}_{\text {hitung }}<\mathrm{t}_{\text {tabel }}$ maka Ho diterima, hal ini berarti pemahaman konsep kelas eksperimen sebelum pembelajaran menggunakan latihan soal terstruktur dan data nilai tes I kelas kontrol sebelum pembelajaran menggunakan latihan soal tidak jauh berbeda atau dinyatakan seimbang. Setelah uji prasyarat analisis terpenuhi selanjutnya dilakukan analisis uji-t (uji hipotesis) dua pihak menggunakan rumus uji-t dan 
dilakukan dengan bantuan Microsoft Excel. Hasil analisis uji-t data nilai tes II kedua kelas sampel diperoleh $t_{\text {hitung }}=5,33$ sedangkan $t_{\text {tabel }}=1,67$ pada taraf signifikan $\alpha=0,05 \mathrm{dan} d \mathrm{k}=n_{1}+n_{2}-2=29+27-2=54$, karena $\mathrm{t}_{\text {hitung }}>$ $\mathrm{t}_{\text {tabel }}$, maka Ho ditolak dan Ha diterima, dengan demikian dapat disimpulkan bahwa pemberian latihan soal terstruktur berpengaruh terhadap pemahaman konsep isomer senyawa hidrokarbon pada siswa kelas XI-IPA SMAN 4 Palangka Raya tahun ajaran 2018/2019.

Pemahaman konsep siswa dapat dilihat berdasarkan perbedaan antara nilai tes I dan tes II siswa pada kelas eksperimen dan kelas kontrol terhadap materi isomer senyawa hidrokarbon. Skor pemahaman konsep siswa pada setiap indikator dapat dilihat pada tabel 3. Peningkatan pemahaman konsep siswa pada setiap indikator disajikan pada tabel berikut:

Tabel 3. Pemahaman Konsep Siswa Kelas Eksperimen dan Kelas Kontrol

\begin{tabular}{lccccc}
\hline & \multirow{2}{*}{$\begin{array}{l}\text { No. Butir } \\
\text { Sndikator }\end{array}$} & \multicolumn{3}{c}{ Peal } & \multicolumn{2}{c}{ Eksperimen } & \multicolumn{2}{c}{ Kontrol } \\
\cline { 3 - 6 } & & Tes I & Tes II & Tes I & Tes II \\
\hline $\begin{array}{l}\text { Menuliskan isomer kerangka pada } \\
\text { senyawa alkana. }\end{array}$ & $1 \mathrm{a}$ & 56,32 & 81 & 51,85 & 68,15 \\
$\begin{array}{l}\text { Menuliskan isomer kerangka pada } \\
\text { senyawa alkena. }\end{array}$ & $1 \mathrm{~b}$ & 37,93 & 77,59 & 19,75 & 43,5 \\
$\begin{array}{l}\text { Menuliskan isomer kerangka pada } \\
\text { senyawa alkuna. }\end{array}$ & $1 \mathrm{c}$ & 31,03 & 94 & 9,26 & 58,3 \\
$\begin{array}{l}\text { Menuliskan isomer posisi pada } \\
\text { senyawa alkena. }\end{array}$ & $2 \mathrm{a}$ & 13,79 & 77 & 18,52 & 66,7 \\
$\begin{array}{l}\text { Menuliskan isomer posisi pada } \\
\text { senyawa alkuna. }\end{array}$ & $2 \mathrm{~b}$ & 6,9 & 93,1 & 7,41 & 63 \\
$\begin{array}{l}\text { Menuliskan isomer geometri (Cis- } \\
\text { Trans) pada senyawa alkena. }\end{array}$ & 3 & 20,69 & 98,3 & 29,6 & 53,7 \\
\hline
\end{tabular}

Data Tabel 3, terlihat bahwa presentase pemahaman konsep tes II lebih besar dibandingkan tes I. Berdasarkan presentase rata-rata perubahan pemahaman konsep pada kelas eksperimen dan kelas kontrol dapat terlihat bahwa presentase pemahaman kelas eksperimen lebih tinggi dari pada presentase pemahaman kelas kontrol. Hal ini dapat diartikan bahwa pembelajaran menggunakan latihan soal terstruktur mampu meningkatkan pemahaman konsep isomer senyawa hidrokarbon dibandingkan dengan pembelajaran menggunakan latihan soal.

Pemahaman konsep siswa dapat dilihat berdasarkan perbedaan antara nilai tes I dan tes II siswa pada kelas eksperimen dan kelas kontrol terhadap materi isomer senyawa hidrokarbon. Skor pemahaman konsep siswa pada setiap indikator dapat dilihat pada Tabel 4. Peningkatan pemahaman konsep siswa pada setiap indikator disajikan pada tabel berikut:

Tabel 4. Pemahaman Konsep Siswa Kelas Eksperimen dan Kelas Kontrol 
DOI: https://doi.org/10.37304/jikt.v11i1.74

\begin{tabular}{lccccc}
\hline & \multirow{2}{*}{$\begin{array}{l}\text { No. Butir } \\
\text { Indikator }\end{array}$} & \multicolumn{3}{c}{ Peal } & \multicolumn{2}{c}{ Eksperimen } & \multicolumn{2}{c}{ Kontrol } \\
\cline { 3 - 6 } & & Tes I & Tes II & Tes I & Tes II \\
\hline $\begin{array}{l}\text { Menuliskan isomer kerangka pada } \\
\text { senyawa alkana. }\end{array}$ & $1 \mathrm{a}$ & 56,32 & 81 & 51,85 & 68,15 \\
$\begin{array}{l}\text { Menuliskan isomer kerangka pada } \\
\text { senyawa alkena. }\end{array}$ & $1 \mathrm{~b}$ & 37,93 & 77,59 & 19,75 & 43,5 \\
$\begin{array}{l}\text { Menuliskan isomer kerangka pada } \\
\text { senyawa alkuna. }\end{array}$ & $1 \mathrm{c}$ & 31,03 & 94 & 9,26 & 58,3 \\
$\begin{array}{l}\text { Menuliskan isomer posisi pada senyawa } \\
\text { alkena. }\end{array}$ & $2 \mathrm{a}$ & 13,79 & 77 & 18,52 & 66,7 \\
$\begin{array}{l}\text { Menuliskan isomer posisi pada senyawa } \\
\text { alkuna. }\end{array}$ & $2 \mathrm{~b}$ & 6,9 & 93,1 & 7,41 & 63 \\
$\begin{array}{l}\text { Menuliskan isomer geometri (Cis-Trans) } \\
\text { pada senyawa alkena. }\end{array}$ & 3 & 20,69 & 98,3 & 29,6 & 53,7 \\
\hline
\end{tabular}

Data Tabel 4, terlihat bahwa persentase pemahaman konsep tes II lebih besar dibandingkan tes I. Berdasarkan persentase rata-rata perubahan pemahaman konsep pada kelas eksperimen dan kelas kontrol dapat terlihat bahwa presentase pemahaman kelas eksperimen lebih tinggi dari pada presentase pemahaman kelas kontrol. Hal ini dapat diartikan bahwa pembelajaran menggunakan latihan soal terstruktur mampu meningkatkan pemahaman konsep isomer senyawa hidrokarbon dibandingkan dengan pembelajaran menggunakan latihan soal.

Dasar dalam penentuan siswa kelompok atas dan siswa kelompok bawah berdasarkan rujukan dari Arikunto (2010) dan hasil nilai ulangan harian yang diperoleh dari guru mata pelajaran di sekolah tempat penelitian. Berdasarkan hasil perhitungan, pada kelas eksperimen 29 × 25\% = 7,25 dan pada kelas kontrol 27 x $25 \%=6,75$ maka diambil 7 orang siswa dari kelompok atas dan 7 orang siswa dari kelompok bawah pada kelas eksperimen dan kontrol , 15 orang siswa pada kelas eksperimen dan 13 orang siswa pada kelas kontrol merupakan kelas sedang yang masing-masing siswa sebanyak 29 dan 27 orang siswa.

Pemahaman konsep siswa dalam menuliskan isomer kerangka pada senyawa alkana ditelusuri menggunakan butir soal nomor 1a.

Tabel 5. Sebaran Skor Tes I dan Tes II Siswa Kelompok Atas dan Kelompok Bawah Kelas Eksperimen dan Kelas Kontrol pada Butir Soal 1a.

\begin{tabular}{cccccccc}
\hline \multicolumn{9}{c}{ Kelompok Atas } \\
\hline \multicolumn{4}{c}{ Tes I } & \multicolumn{2}{c}{ Tes II } & \multicolumn{4}{c}{ Tes I } & \multicolumn{2}{c}{ Tes II } \\
\hline Skor & $\sum$ siswa & Skor & $\sum$ siswa & Skor & $\sum$ siswa & Skor & $\sum$ siswa \\
\hline 0 & 1 & 3 & 1 & 1 & 1 & 3 & 1 \\
1 & 2 & 1,8 & 2 & 2 & 5 & 3 & 1 \\
2 & 3 & 2,4 & 3 & & & 2,4 & 4 \\
3 & 1 & 3 & 1 & 3 & 1 & 3 & 1 \\
\hline
\end{tabular}

Kelompok Bawah 


\begin{tabular}{cccccccc}
\hline & \multicolumn{3}{c}{ Kelas Eksperimen } & \multicolumn{3}{c}{ Kelas Kontrol } \\
\hline \multicolumn{2}{c}{ Tes I } & \multicolumn{2}{c}{ Tes II } & \multicolumn{2}{c}{ Tes I } & \multicolumn{2}{c}{ Tes II } \\
\hline Skor & $\sum$ siswa & Skor & $\sum$ siswa & Skor & $\sum$ siswa & Skor & $\sum$ siswa \\
\hline \multirow{2}{*}{0} & 2 & 2,4 & 1 & 0 & 1 & 1,2 & 1 \\
& & 1,8 & 1 & & & 1,2 & 1 \\
& & 1,2 & 1 & & & 1,8 & 3 \\
\multirow{4}{*}{1} & & 1,8 & 1 & 1 & 6 & 2,4 & 1 \\
& 5 & 2,4 & 1 & & & 3 & 1 \\
& & 3 & 2 & & & & \\
\hline
\end{tabular}

Tabel 5 menunjukkan bahwa sebaran skor tes I kelompok atas kelas eksperimen dari skor 0 sampai 3, kemudian pada tes II menyebar dari skor 1,8 sampai 3 sedangkan sebaran skor tes I kelompok atas kelas kontrol dari skor 1 sampai 3, kemudian pada tes II menyebar dari skor 2,4 sampai 3. Sebaran skor tes I pada kelompok bawah kelas eksperimen dari skor 0 sampai 1, kemudian pada tes II menyebar dari skor 1,2 sampai 3 sedangkan sebaran skor tes I kelompok bawah kelas kontrol dari skor 0 sampai 1, kemudian pada tes II menyebar dari skor 1,2 sampai 3. Tabel 5 menunjukkan terjadinya perubahan skor yang sangat nampak pada siswa kelompok bawah kelas eksperimen di banding kelompok bawah kelas kontrol.

Pemahaman konsep siswa dalam menuliskan isomer kerangka pada senyawa alkena ditelusuri menggunakan butir soal nomor $1 \mathrm{~b}$.

Tabel 6. Sebaran Skor Tes I dan Tes II Siswa Kelompok Atas dan Kelompok Bawah Kelas Eksperimen dan Kelas Kontrol pada Butir Soal 1b

\begin{tabular}{|c|c|c|c|c|c|c|c|}
\hline \multicolumn{8}{|c|}{ Kelompok Atas } \\
\hline \multicolumn{4}{|c|}{ Kelas Eksperimen } & \multicolumn{4}{|c|}{ Kelas Kontrol } \\
\hline \multicolumn{2}{|c|}{ Tes I } & \multicolumn{2}{|c|}{ Tes II } & \multicolumn{2}{|c|}{ Tes I } & \multicolumn{2}{|c|}{ Tes II } \\
\hline Skor & $\sum$ siswa & Skor & $\sum$ siswa & Skor & $\sum$ siswa & Skor & $\sum$ siswa \\
\hline 0 & 1 & \multirow{3}{*}{3} & \multirow{3}{*}{3} & 0 & 1 & \multirow{2}{*}{2,25} & \multirow{2}{*}{2} \\
\hline 1 & 1 & & & 1 & 1 & & \\
\hline 2 & 1 & & & \multirow{2}{*}{1} & \multirow{2}{*}{2} & 1,5 & 1 \\
\hline \multirow{2}{*}{2} & \multirow{2}{*}{3} & 3 & 1 & & & 3 & 1 \\
\hline & & 2,25 & 2 & 2 & 1 & 2,25 & 1 \\
\hline 3 & 1 & 3 & 1 & 2 & 1 & 3 & 2 \\
\hline \multicolumn{8}{|c|}{ Kelompok Bawah } \\
\hline \multicolumn{4}{|c|}{ Kelas Eksperimen } & \multicolumn{4}{|c|}{ Kelas Kontrol } \\
\hline \multicolumn{2}{|c|}{ Tes I } & \multicolumn{2}{|c|}{ Tes II } & \multicolumn{2}{|c|}{ Tes I } & \multicolumn{2}{|c|}{ Tes II } \\
\hline Skor & $\sum$ siswa & Skor & $\sum$ siswa & Skor & $\sum$ siswa & Skor & $\sum$ siswa \\
\hline \multirow{3}{*}{0} & \multirow{3}{*}{7} & 0,75 & 1 & 0 & 1 & 1,5 & 1 \\
\hline & & 1,5 & 1 & 0 & 5 & 0 & 5 \\
\hline & & 3 & 5 & 1 & 1 & 0 & 1 \\
\hline
\end{tabular}


Tabel 6 menunjukkan bahwa sebaran skor tes I kelompok atas kelas eksperimen dari skor 0 sampai 3, kemudian pada tes II menyebar dari skor 2,25 sampai 3 sedangkan sebaran skor tes I kelompok atas kelas kontrol dari skor 0 sampai 3, kemudian pada tes II menyebar dari skor 1,5 sampai 3. Sebaran skor tes I pada kelompok bawah kelas eksperimen dari skor 0, kemudian pada tes II menyebar dari skor 0,75 sampai 3 sedangkan sebaran skor tes I kelompok bawah kelas kontrol dari skor 0 sampai 1, kemudian pada tes II menyebar dari skor 0 sampai 1,5. Tabel 6 juga menunjukkan perubahan skor yang sangat terlihat pada siswa kelompok bawah kelas eksperimen dibanding kelompok bawah kelas kontrol.

Pemahaman konsep siswa dalam menuliskan isomer kerangka dari senyawa alkuna ditelusuri menggunakan butir soal nomor $1 \mathrm{c}$.

Tabel 7. Sebaran Skor Tes I dan Tes II Siswa Kelompok Atas dan Kelompok Bawah Kelas Eksperimen dan Kelas Kontrol pada Butir Soal 1c

\begin{tabular}{|c|c|c|c|c|c|c|c|}
\hline \multicolumn{8}{|c|}{ Kelompok Atas } \\
\hline \multicolumn{4}{|c|}{ Kelas Eksperimen } & \multicolumn{4}{|c|}{ Kelas Kontrol } \\
\hline \multicolumn{2}{|c|}{ Tes I } & \multicolumn{2}{|c|}{ Tes II } & \multicolumn{2}{|c|}{ Tes I } & \multicolumn{2}{|c|}{ Tes II } \\
\hline Skor & $\sum$ siswa & Skor & $\sum$ siswa & Skor & $\sum$ siswa & Skor & $\sum$ siswa \\
\hline 1 & 2 & \multirow{5}{*}{2} & \multirow{5}{*}{7} & \multirow{2}{*}{0} & \multirow{2}{*}{4} & 0,5 & 1 \\
\hline \multirow[t]{4}{*}{2} & 5 & & & & & 1,5 & 3 \\
\hline & & & & 0 & 1 & & \\
\hline & & & & 1 & 1 & 2 & 3 \\
\hline & & & & 2 & 1 & & \\
\hline \multicolumn{8}{|c|}{ Kelompok Bawah } \\
\hline \multicolumn{4}{|c|}{ Kelas Eksperimen } & \multicolumn{4}{|c|}{ Kelas Kontrol } \\
\hline \multicolumn{2}{|c|}{ Tes I } & \multicolumn{2}{|c|}{ Tes II } & \multicolumn{2}{|c|}{ Tes I } & \multicolumn{2}{|c|}{ Tes II } \\
\hline Skor & $\sum$ siswa & Skor & $\sum$ siswa & Skor & $\sum$ siswa & Skor & $\sum$ siswa \\
\hline \multirow{3}{*}{0} & \multirow{3}{*}{7} & 1,5 & 1 & 0 & 5 & 0,5 & 5 \\
\hline & & \multirow{2}{*}{2} & \multirow[t]{2}{*}{6} & 0 & 1 & \multirow{2}{*}{1,5} & \multirow{2}{*}{2} \\
\hline & & & & 1 & 1 & & \\
\hline
\end{tabular}

Tabel 7 menunjukkan bahwa sebaran skor tes I kelompok atas kelas eksperimen dari skor 1 sampai 2, kemudian pada tes II menyebar menjadi skor 2 sedangkan sebaran skor tes I kelompok atas kelas kontrol dari skor 0 sampai 2, kemudian pada tes II menyebar dari skor 0,5 sampai 2. Sebaran skor tes I pada kelompok bawah kelas eksperimen dari skor 0, kemudian pada tes II menyebar dari skor 1,5 sampai 2 sedangkan sebaran skor tes I kelompok bawah kelas kontrol dari skor 0 sampai 1, kemudian pada tes II menyebar dari skor 0,5 sampai 1,5. Tabel 7 juga menunjukkan perubahan skor terjadi lebih banyak pada siswa kelompok bawah kelas eksperimen di banding kelompok bawah kelas control.

Pemahaman konsep siswa dalam menuliskan isomer posisi dari senyawa alkena ditelusuri menggunakan butir soal nomor $2 \mathrm{a}$.

Tabel 8. Sebaran Skor Tes I dan Tes II Siswa Kelompok Atas dan Kelompok Bawah Kelas Eksperimen dan Kelas Kontrol pada Butir Soal 2a 


\begin{tabular}{|c|c|c|c|c|c|c|c|}
\hline \multicolumn{8}{|c|}{ Kelompok Atas } \\
\hline \multicolumn{4}{|c|}{ Kelas Eksperimen } & \multicolumn{4}{|c|}{ Kelas Kontrol } \\
\hline \multicolumn{2}{|c|}{ Tes I } & \multicolumn{2}{|c|}{ Tes II } & \multicolumn{2}{|c|}{ Tes I } & \multicolumn{2}{|c|}{ Tes II } \\
\hline Skor & $\sum$ siswa & Skor & $\sum$ siswa & Skor & $\sum$ siswa & Skor & $\sum$ siswa \\
\hline \multirow{2}{*}{0} & \multirow{2}{*}{2} & 2 & 1 & \multirow{2}{*}{0} & \multirow[b]{2}{*}{2} & 1 & 1 \\
\hline & & 3 & 1 & & & 3 & 1 \\
\hline \multirow{2}{*}{1,5} & \multirow{2}{*}{2} & 3 & 1 & \multirow{3}{*}{3} & \multirow{3}{*}{5} & \multirow{3}{*}{3} & \multirow{3}{*}{5} \\
\hline & & 2 & 1 & & & & \\
\hline 3 & 3 & 3 & 3 & & & & \\
\hline \multicolumn{8}{|c|}{ Kelompok Bawah } \\
\hline \multicolumn{4}{|c|}{ Kelas Eksperimen } & \multicolumn{4}{|c|}{ Kelas Kontrol } \\
\hline \multicolumn{2}{|c|}{ Tes I } & \multicolumn{2}{|c|}{ Tes II } & \multicolumn{2}{|c|}{ Tes I } & \multicolumn{2}{|c|}{ Tes II } \\
\hline Skor & $\sum$ siswa & Skor & $\sum$ siswa & Skor & $\sum$ siswa & Skor & $\sum$ siswa \\
\hline \multirow{4}{*}{0} & \multirow{4}{*}{7} & 1 & 1 & \multirow{4}{*}{0} & \multirow{4}{*}{7} & 0 & 3 \\
\hline & & 2 & 1 & & & 1 & 1 \\
\hline & & 3 & 5 & & & 2 & 1 \\
\hline & & & & & & 3 & 2 \\
\hline
\end{tabular}

Tabel 8 menunjukkan bahwa sebaran skor tes I kelompok atas kelas eksperimen dari skor 0 sampai 3, kemudian pada tes II menyebar dari skor 2 sampai 3 sedangkan sebaran skor tes I kelompok atas kelas kontrol dari skor 0 sampai 3, kemudian pada tes II menyebar dari skor 1 sampai 3. Sebaran skor tes I pada kelompok bawah kelas eksperimen dari skor 0, kemudian pada tes II menyebar dari skor 1 sampai 3 sedangkan sebaran skor tes I kelompok bawah kelas kontrol dari skor 0 , kemudian pada tes II menyebar dari skor 0 sampai 3 . Tes II dikerjakan setelah diberikan perlakuan berupa pembelajaran langsung menggunakan latihan soal terstruktur pada kelas eksperimen dan pembelajaran langsung menggunakan latihan soal tak terstruktur pada kelas kontrol. Perubahan skor sangat Nampak dan banyak terjadi pada siswa kelompok bawah kelas eksperimen dibanding kelompok bawah kelas kontrol.

Pemahaman konsep siswa dalam menuliskan isomer posisi dari senyawa alkuna ditelusuri menggunakan butir soal nomor $2 b$.

Tabel 9. Sebaran Skor Tes I dan Tes II Siswa Kelompok Atas dan Kelompok Bawah Kelas Eksperimen dan Kelas Kontrol pada Butir Soal 2b

\begin{tabular}{cccccccc}
\hline \multicolumn{8}{c}{ Kelompok Atas } \\
\hline \multicolumn{3}{c}{ Tes I } & \multicolumn{2}{c}{ Tes II } & \multicolumn{2}{c}{ Tes I } & \multicolumn{2}{c}{ Tes II } \\
\hline Skor & $\sum$ siswa & Skor & $\sum$ siswa & Skor & $\sum$ siswa & Skor & $\sum$ siswa \\
\hline \multirow{2}{*}{0} & 4 & 2 & 1 & 0 & 6 & 1 & 2 \\
1,5 & 2 & 3 & 3 & & & 3 & 4 \\
3 & 1 & 3 & 1 & 3 & 1 & 3 & 1 \\
\hline \multicolumn{8}{c}{ Kelompok Bawah } \\
\hline \multicolumn{8}{c}{ Kelas Eksperimen } \\
\hline
\end{tabular}




\begin{tabular}{cccccccc}
\hline \multicolumn{2}{c}{ Tes I } & \multicolumn{2}{c}{ Tes II } & \multicolumn{2}{c}{ Tes I } & \multicolumn{2}{c}{ Tes II } \\
\hline Skor & $\sum$ siswa & Skor & $\sum$ siswa & Skor & $\sum$ siswa & Skor & $\sum$ siswa \\
\hline \multirow{2}{*}{0} & \multirow{2}{*}{7} & 1 & 1 & & & 0 & 3 \\
& \multirow{2}{*}{3} & 6 & \multirow{2}{*}{0} & 7 & 1 & 1 \\
& & & & & & 2 & 2 \\
& & & & & & 3 & 1 \\
\hline
\end{tabular}

Tabel 9 menunjukkan bahwa sebaran skor tes I kelompok atas kelas eksperimen dari skor 0 sampai 3, kemudian pada tes II menyebar dari skor 2 sampai 3 sedangkan sebaran skor tes I kelompok atas kelas kontrol dari skor 0 sampai 3, kemudian pada tes II menyebar dari skor 1 sampai 3. Sebaran skor tes I pada kelompok bawah kelas eksperimen dari skor 0, kemudian pada tes II menyebar dari skor 1 sampai 3 sedangkan sebaran skor tes I kelompok bawah kelas kontrol dari skor 0, kemudian pada tes II menyebar dari skor 0 sampai 3 . Tabel 9 menunjukkan bahwa LKS latihan soal terstruktur lebih nampak berpengaruh terhadap siswa kelas bawah dimana LKS latihan soal terstruktur bermanfaat bagi siswa kelompok bawah terbukti dari perubahan skor yang sangat terlihat pada siswa kelompok bawah kelas eksperimen di banding kelompok bawah kelas kontrol.

Pemahaman konsep siswa dalam menuliskan isomer geometri (Cis-Trans) dari senyawa alkena ditelusuri menggunakan butir soal nomor 3 .

Tabel 10. Sebaran Skor Tes I dan Tes II Siswa Kelompok Atas dan Kelompok Bawah Kelas Eksperimen dan Kelas Kontrol pada Butir Soal 3

\begin{tabular}{|c|c|c|c|c|c|c|c|}
\hline \multicolumn{8}{|c|}{ Kelompok Atas } \\
\hline \multicolumn{4}{|c|}{ Kelas Eksperimen } & \multicolumn{4}{|c|}{ Kelas Kontrol } \\
\hline \multicolumn{2}{|c|}{ Tes I } & \multicolumn{2}{|c|}{ Tes II } & \multicolumn{2}{|c|}{ Tes I } & \multicolumn{2}{|c|}{ Tes II } \\
\hline Skor & $\sum$ siswa & Skor & $\sum$ siswa & Skor & $\sum$ siswa & Skor & $\sum$ siswa \\
\hline 0 & 4 & \multirow{4}{*}{2} & \multirow{4}{*}{7} & 0 & 1 & 2 & 1 \\
\hline 1 & 1 & & & & \multirow{2}{*}{2} & 1 & 1 \\
\hline \multirow[t]{2}{*}{2} & 2 & & & 1 & & 2 & 1 \\
\hline & & & & 2 & 4 & 2 & 4 \\
\hline \multicolumn{8}{|c|}{ Kelompok Bawah } \\
\hline \multicolumn{4}{|c|}{ Kelas Eksperimen } & \multicolumn{4}{|c|}{ Kelas Kontrol } \\
\hline \multicolumn{2}{|c|}{ Tes I } & \multicolumn{2}{|c|}{ Tes II } & \multicolumn{2}{|c|}{ Tes I } & \multicolumn{2}{|c|}{ Tes II } \\
\hline Skor & Esiswa & Skor & $\sum$ siswa & Skor & $\sum$ siswa & Skor & $\sum$ siswa \\
\hline 0 & 5 & & & & & 0 & 3 \\
\hline \multirow{2}{*}{2} & \multirow{2}{*}{2} & 2 & 7 & 0 & 7 & 1 & 1 \\
\hline & & & & & & 2 & 3 \\
\hline
\end{tabular}

Tabel 9 menunjukkan bahwa sebaran skor tes I kelompok atas kelas eksperimen dari skor 0 sampai 2, kemudian pada tes II menyebar dari skor 2 sedangkan sebaran skor tes I kelompok atas kelas kontrol dari skor 0 sampai 2, kemudian pada tes II menyebar dari skor 1 sampai 2. Sebaran skor tes I pada kelompok bawah kelas eksperimen dari skor 0 sampai 2, kemudian pada tes II menyebar dari skor 2 sedangkan sebaran skor tes I kelompok bawah kelas kontrol 
dari skor 0, kemudian pada tes II menyebar dari skor 0 sampai 2. Perubahan skor sangat terlihat pada siswa kelompok bawah kelas eksperimen di banding kelompok bawah kelas kontrol.

Berdasarkan hasil penelitian menunjukkan bahwa LKS latihan soal terstruktur lebih nampak berpengaruh terhadap siswa kelas bawah dimana LKS latihan soal terstruktur bermanfaat bagi siswa kelompok bawah yang membutuhkan tuntunan dalam pembelajaran terutama pada materi isomer senyawa hidrokarbon.

\section{SIMPULAN}

Berdasarkan hasil statistik menggunakan uji-t menunjukkan bahwa pemberian latihan soal terstruktur setelah pembelajaran langsung berpengaruh terhadap pemahaman konsep isomer senyawa hidrokarbon pada siswa kelas XI IPA SMAN 4 Palangka Raya tahun ajaran 2018/2019. Rata-rata pemahaman konsep siswa kelas eksperimen $(85,60)$ lebih tinggi dari kelas kontrol $(59,25)$. LKS latihan soal terstruktur memberikan pengaruh terhadap siswa kelompok bawah dan siswa kelompok atas.

\section{DAFTAR PUSTAKA}

Arikunto, Suharsimi. (2006). Prosedur Penelitian Suatu Pendekatan Praktik edisi revisi VI. Jakarta: Rineka Aksara.

Arikunto, Suharsimi. (2007). Dasar-dasar evaluasi pendidikan. Jakarta: Bumi Aksara.

Arikunto, Suharsimi. (2010). Prosedur Penelitian Suatu Pendekatan Praktik. Jakarta : PT. Rineka Cipta.

Arsyad, Ashar. (2010). Media Pembelajaran. Jakarta: PT Raja Grafindo Persada.

Asi, Y., Abudarin and Asi, N.B. 2019. Pengaruh Pemberian Latihan Soal Terstruktur Setelah Pembelajaran Langsung Terhadap Pemahaman Konsep Ikatan Ion Pada Siswa Kelas X IPA SMA Negeri 4 Palangka Raya Tahun Ajaran 2018/2019. Jurnal Ilmiah Kanderang Tingang. 10, 1 (Jun. 2019), 104-111.

Aunurrahman. (2009). Belajar dan Pembelajaran. Bandung: Alfabeta Bandung.

Belawati, T. (2003). Penggunaan Bahan Ajar. Jakarta: Universitas Terbuka.

Dahar, Ratna Wilis. 2011. Teori-Teori Belajar \& Pembelajaran. Jakarta: Erlangga.

Djamarah, Syaiful Bahri, dan Aswan Zain. 2006. Strategi Belajar Mengajar. Jakarta: Bumi Aksara.

Emzir. (2014). Metodologi Penelitian Pendidikan Kuantitatif dan Kualitatif. Jakarta: PT Raja Grafindo Persada.

Fessenden, J.R \& Fessenden S.J. (2010). Dasar-Dasar Kimia Organik. Jakarta: Bina Rupa Publisher.

Hamalik, Oemar. (2007). Proses Belajar Mengajar. Jakarta: Bumi Aksara.

Hamalik, Oemar. (2014). Psikologi Belajar dan Mengajar. Bandung: Sinar Baru Algensindo.

Handayani, Elin Nisa. (2014). Pemahaman Konsep Persamaan Rekasi Pasca Pembelajaran Menggunakan Metode Resitasi Berbantuan LKS Latihan Soal Terstruktur Pada Siswa Kelas X Semester 2 SMAN 5 Palangka 
Raya Tahun Ajaran 2013/2014. Skripsi. Tidak diterbitkan : Universitas Palangka Raya. Palangka Raya.

Johari, J.M.C \& Rachmawati, M. (2006). Kimia SMA dan MA untuk Kelas X. Jakarta : Esis.

Kamus Besar Bahasa Indonesia (KBBI), Kamus Versi Online. Diakses pada tanggal 15 Maret 2018, dari http://kbbi.web.id/paham.

Mairing, Pasini Jackson. 2017. Statistika Pendidikan. Yogyakarta: Andi.

Maulia. (2012). Pengaruh Pengunaan LKS Penyelesaian Soal Terstruktur Terhadap Pemahaman Konsep Hukum Avogadro Pada Siswa Kelas XI IPA-1 SMAN 3 Palangka Raya Tahun Pelajaran 2011/2012. Skripsi. Tidak diterbitkan: Universitas Palangka Raya. Palangka Raya.

Mutmainah. (2013). Pengaruh Pemberian LKS-Penyelesaian Soal Terstruktur terhadap Pemahaman Konsep pH Larutan Asam Pada Siswa Kelas XI IPA SMAN-1 Menthobi Raya Tahun Ajaran 2002/2013. Skripsi. Tidak diterbitkan: Universitas Palangka Raya. Palangka Raya.

Otania, M., Abudarin and Asi, N.B. 2019. Pengaruh Pemberian Latihan Soal Terstruktur Setelah Pembelajaran Langsung Terhadap Pemahaman Konsep Ikatan Kovalen Pada Siswa Kelas X IPA SMA Negeri 4 Palangka Raya Tahun Ajaran 2018/2019. Jurnal Ilmiah Kanderang Tingang. 10, 1 (Jun. 2019), 95-103.

Prastowo, Andi. (2015). Panduan Kreatif Membuat Bahan Ajar Inovatif. Yogyakarta: DIVA Press.

Pribadi, Benny A. (2009). Model desain sistem pembelajaran. Jakarta: Dian Rakyat.

Rinjani, S. (2012). Pengaruh Pemberian LKS (lembar kerja siswa) Terhadap Pemahaman Konsep Hukum Hess Pada Siswa Kelas XI IPA 2 SMA Muhammadiyah 1 Palangka Raya Tahun Ajaran 2011/2012. Skripsi. Tidak diterbitkan: Universitas Palangka Raya. Palangka Raya.

Salirawati, dkk. (2007). Belajar Kimia Secara Menarik untuk SMA/MA kelas X. Jakarta: PT. Grasindo.

Sari, Norita Desi. (2015). Kesulitan Memahami Konsep Isomer Senyawa Hidrokarbon Pada Siswa Kelas XI MIA SMA Negeri Di Kota Muara Teweh Semester Genap Tahun Ajaran 2014/2015. Skripsi. Tidak diterbitkan : Universitas Palangka Raya. Palangka Raya.

Sion, Holten dkk. (2017). Pedoman Penulisan Skripsi. Palangka Raya: Fakultas Keguruan Dan Ilmu Pendidikan Universitas Palangka Raya.

Sugiyono. (2014). Metode Penelitian Kuantitatif, Kualitatif, dan R\&D. Bandung: Alfabeta.

Sumbodo, Rijal Israwanto. (2017). Peningkatan Pemahaman Konsep Hubungan Hasil Kali Kelarutan Dengan pH Hasil Pembelajaran Menggunakan LKS-Latihan Soal Terstruktur Pada Siswa Kelas XI IPA SMA Negeri 3 Palangka Raya Tahun Ajaran 2016/2017. Skripsi. Tidak diterbitkan: Universitas Palangka Raya. Palangka Raya.

Susanto Ahmad. (2013). Teori Belajar \& Pembelajaran. Jakarta: Prenadamedia Group.

Suyono \& Hariyanto. (2014). Belajar dan Pembelajaran. Bandung: PT Remaja Rosdakarya. 
Tabatai, Husein. (2008). Analogi Sebuah Logika. Diakses pada tanggal 17 Maret 2018. http://cakrawalaeinstein.com.

Usman, H, dan Akbar, P.S. (2004). Metodologi Penelitian Sosial. Jakarta: PT Bumi Aksara.

Winata Putra, Udin S. (2007). Belajar dan pembelajaran. Jakarta: Universitas Terbuka. 